\title{
Analysis Of Risk Factors That Influence The Lumbago Event In Hand-Rolled Clove Cigarette Workers At Margantara Jaya Cigarette Factories
}

Dewi Zuniawati ${ }^{1}$, Indasah ${ }^{2}$, Prima Dewi ${ }^{3}$

${ }^{1}$ Students of the Master Program in Public Health, Strada Indonesia Health Sciences Institute

${ }^{2}$ Lecturer in the Master Program in Public Health, Strada Indonesia Health Sciences Institute

${ }^{3}$ Lecturer in the Master Program in Public Health, Strada Indonesia Health Sciences Institute

Email:

zuniawati1395@gmail.com

Received : October 5, 2020

Accepted : November 27, 2020

Published : November 30, 2020
Lumbago or low back pain is one of the musculoskeletal disorders, that result from incorrect ergonomics. Lumbago is problem in many countries, because it affects productivity of the work. WHO estimates that incidence of low back pain reaching $60-70 \%$ in early adulthood. The purpose of this study was to analyze of working period, the length of sitting, and sitting position in lumbago event and look for the most dominant factors among the three variables at Margantara Jaya Tulungagung Cigarette Factory.

The study design used quantitative research design with "cross sectional" approach. The sampling technique was Simple Random Sampling with 135 respondents. The data analysis techniques were using the Logistic Regression test.

The result showed from 135 respondents was found that 115 respondents $(85 \%)$ had positive lumbago. $59 \%$ had more than 10 years of service, $84 \%$ sat for more than 9 hours per day and $92 \%$ were in ergonomic sitting position. Based on the Logistic Regression test, it showed a significance value of $\mathrm{p}$-value $=$ $0,000<\alpha=0.05$, it meant that $\mathrm{H} 0$ is rejected and $\mathrm{H} 1$ is accepted. Based on the value of $\operatorname{Exp}(\mathrm{B})$ with the highest value $\operatorname{Exp}(B)=187,663$ it can be concluded that the most dominant factor that affecting the lumbago event is the sitting position.

There is a relationship between the factors of work period, length of work and sitting position of lumbago incidents in hand- rolled clove cigarette workers and the most dominant factor that affecting the lumbago event is the sitting position.

Keywords: Lumbago, Working Period, Sitting Position

Copyright (C) 2020 IIK STRADA Indonesia All right reserved.

This is an open-acces article distributed under the terms of the Creative Commons Attribution-ShareAlike 4.0 International License.

\section{INTRODUCTION}

Lumbago or low back pain (LBP) is one of the musculoskeletal disorders, it is the result of incorrect ergonomics. Back pain can occur in various work situations, If the workers sit for a long time in a static position, the risk is greatest, because it will cause continuous muscle contraction and narrowing of the arteries. In narrowing of blood vessels, the blood flow is blocked and ischemia is occurred, the system lacks oxygen and nutrients, while long muscle contractions will cause lactic acid buildup, both of which cause pain. Back pain is a problem in many countries, because it often affects productivity of the work. In 2013, World Health Organization (WHO) estimates that the incidence of low back pain reaching $60-70 \%$ occurs in early adulthood. The data for the number of lumbago sufferers in 
Indonesia has not known yet, but it is estimated that Lumbago sufferers in Indonesia vary from $7.6 \%$ to $37 \%$ of the total population in Indonesia (Lailani, 2013). It is for about $80 \%$ of a lifetime's population has ever eaten lumbago. At any time, more than $10 \%$ of the population has a lot of lumbago. The incidence of lumbago in some developing countries is approximately $15-20 \%$ of the total contribution, most of which is the recovery of acute and chronic backs. About $80 \%$ of the population that has experienced lower back pain has never been in pregnancy.

Some risk factors that affect lumbago events are individual factors (age, body mass index, gender, smoking) and occupational factors (workload, duration of work, work position, repetition, years of service) (Parjoto, 2007). Working period factors, length of sitting and sitting position are factors of work that play an important role in the occurrence of lumbago.(Umami et al., 2014). Lumbago is a pain in the lower back area which is one of the musculoskeletal disorders caused by poor body activity. If the activity is carried out continuously over a period of years, of course, it can cause body disorders, especially disorders of the lower back which will cause the pain (Noor, 2012).Back pain or lumbago is caused by tension in the vertebral, especially in the lumbar (Nurmianto, 2015).

By knowing the risk of long sitting against Lumbago complaints to workers, a solution is given so that they pay attention to their sitting position and take the time to stretch the muscles at work to prevent or reduce the incidence of lumbago. This can encourage researchers to conduct research on the analysis of risk factors that affect the incidence of lumbago in hand-rolled kretek cigarettes at the Mangantara Jaya Cigarette Factory in Tulungagung.

\section{MATERIALS AND METHODS}

This study used quantitative research by using a correlational study with a cross sectional design. The population in this study was all in hand-rolled clove cigarette workers estimated 205 people. The sampling technique is Simple Random Sampling with a large sample calculation in obtaining a sample of 135 respondents. The instrument that used for the data collection in this study is the observation sheet on the variable length of work, sitting time and sitting position while the lumbago variable uses the laseque test with laseque examination. The statistical analysis is quantitative analysis with data analysis techniques by using the Logistic Regression test. The location of the study was at at Margantara Jaya Tulungagung Cigarette Factory. The independent variable of working period, the length of sitting, and sitting position while the dependent variable was lumbago. This research has also been done through the Institute of Health Science IIK STRADA SK. This research has also passed the ethical test carried out through the Health Sciences Institute IIK STRADA SK No. 970 / KEPK / V / 2019.

\section{RESULTS}

The incidence of lumbago was found in th study on th factor of working period, the length of sitting, and sitting position. The results are in table 1- 4

Table 1. Respondents Based on the Lumbago

\begin{tabular}{cccc}
\hline No. & Lumbago & Total & Presentase (\%) \\
\hline 1. & Positive & 115 & 85 \\
2. & Negative & 20 & 15 \\
\hline Total & & 135 & 100 \\
\hline
\end{tabular}

Based on table 1, it is found that most respondents experienced lumbago incidence as many as 115 respondents $(85 \%)$.

Table 2. Respondents Based on Working Period

\begin{tabular}{cccc}
\hline No. & Working Period & Total & Presentase (\%) \\
\hline 1. & $<6$ year & 24 & 18 \\
2. & $6-10$ year & 30 & 23 \\
3. & $>10$ year & 81 & 59 \\
\hline Total & & 135 & 100 \\
\hline
\end{tabular}

Based on table 2, more than half of respondents gained> 10 year of service by 81 respondents (59\%)

.Table 3. Respondents Based on Length of Sitting

\begin{tabular}{cccc}
\hline No. & Length of Sitting & Total & Presentase (\%) \\
\hline 1. & $\leq 8$ jam & 21 & 16 \\
2. & $>9$ jam & 114 & 84 \\
\hline Total & & 135 & 100 \\
\hline
\end{tabular}


Based on table 3, most respondents took $>9$ hours sitting time as many as 114 respondents (84\%).

Table 4. Respondents Based on Sitting Position

\begin{tabular}{cccc}
\hline No. & Sitting Position & Total & Presentase (\%) \\
\hline 1. & No ergonomic & 122 & 92 \\
2. & Ergonomic & 13 & 8 \\
\hline Total & & 135 & 100 \\
\hline
\end{tabular}

Based on table 4, it is found that most of the respondents are in a non-ergonomic position as many as 122 respondents $(92 \%)$.

Table 5. Analysis Results of Factors Affecting the Incidence of Lumbago in Hand-Rolled Kretek Cigarette Workers in the working area of the Margantara Jaya Cigarette Factory, Gesikan Village, Pakel District, Tulungagung Regency

Omnibus test of model coefficients

\begin{tabular}{lllll}
\hline \multirow{2}{*}{ Step } & & Chi-square & Df & Sig. \\
\cline { 3 - 5 } & Step & 72.320 & 3 & .000 \\
& Block & 72.320 & 3 & .000 \\
& Model & 72.320 & 3 & .000 \\
\hline
\end{tabular}

\begin{tabular}{lllc}
\hline Model Summary & & & \\
\hline Step & -2 Log likelihood & $\begin{array}{l}\text { Cox \& } \\
\text { Square }\end{array}$ & Snell RNagelkerke R Square \\
\hline 1 & $40.941^{\mathrm{a}}$ & .415 & .730 \\
\hline
\end{tabular}

\begin{tabular}{lllllll}
\hline \multicolumn{2}{l}{ Variables in the Equation } \\
\hline & B & S.E. & Wald & Df & Sig. & Exp(B) \\
\hline${\text { Step } 1^{\text {a }}}^{\text {X1 }}$ & .547 & 8.287 & 1 & .004 & .207 \\
& X2 & .889 & 9.688 & 1 & .002 & .063 \\
& X3 & 1.440 & 13.210 & 1 & .000 & 187.633 \\
\hline & Constant & 1.958 & .005 & 1 & .946 & 1.143 \\
\hline
\end{tabular}

Variable(s) entered on step 1: X1, X2, X3. Based on table 5, it shows that the incidence of Lumbago in hand-rolled kretek cigarette workers is influenced by factors of work tenure, length of work, and sitting position. The wrong sitting position with a chair that is not ergonomic will cause lower back pain. Lower back pain is caused by excessive or continuous muscle contraction and narrowing of the blood vessels, both of which cause lumbar pain. The working period is one of the factors that influence the incidence of lumbago. A long period of work will cause the disc cavity to permanently narrow and will result in degeneration of the spine which will lead to lumbago. The incidence of lumbago is influenced by the length of sitting with a duration of 8-9 hours per day. The length of sitting is related to the physical condition of the hand-rolled kretek cigarette workers. Hard physical work will affect the work of the muscles. If the work lasts for a long time without rest, it will decrease the body's ability and result in fatigue in the back muscle tissue, especially the lumbar muscles.

The most dominant factor affecting Lumbago is the sitting position factor. This is because the handrolled kretek cigarette workers work in the wrong sitting position which can cause a condition where the transfer of energy from the muscles to the skeletal tissue is inefficient, causing fatigue which can lead to lumbago. Lumbago is a pain in the lower back, which is a musculoskeletal disorder caused by poor body activity. Risk factors that affect the incidence of lumbago include individual factors (age, body mass index, sex, smoking) and occupational factors (workload, duration or length of work, work position, repetition, years of service).

\section{DISCUSSION}

From the results of logistic regression analysis, it is known that the omnibus value of the model test shows p-value $=0.000<\alpha 0.05$ so that $\mathrm{H} 0$ is rejected and $\mathrm{H} 1$ is accepted, which means that there is a 
joint influence on the factors of tenure, sitting time, and sitting position on the incidence of lumbago. for hand-rolled kretek cigarette workers at Margantara Jaya Cigarette Factory in Tulungagung.

Based on the value of Exp (B), it can be seen that the factor that most influences the incidence of lumbago in hand-rolled kretek cigarette workers at Margantara Jaya Tulungagung Cigarette Factory is the factor that occupies the position with the highest $\operatorname{Exp}(\mathrm{B})$ value $=187,663$. The results showed that the sitting factor was the most dominant factor. This suggests that sitting incorrectly can cause pain. Therefore, it is necessary to pay attention to how to sit properly and the use of a lumbar support when sitting really helps reduce the risk of Lumbago. Lumbago can be caused by various musculoskeletal diseases, psychological disorders and incorrect mobilization (Mutataqin, 2008). Lumbago, an unpleasant condition of childhood limitations and acute pain in the area of the fifth and sacral lumbar joints (L5-S1). Pain in the lower back felt by the sufferer can be clear or vague and spread or localized (Defriyan, 2011).

Risk factors for lumbago include individual factors (age, body mass index, gender, smoking) and occupational factors (workload, duration or length of work, work position, reps, years of work). The longer a person's work period, the greater risk for experiencing a Lumbago incident (Santoso, 2013). The results of research conducted by Syuhada, Suwando, Setyaningsih, 2018 regarding the risk factors for low back pain in tea picking workers in cianter tea plantations in Subang Regency, it was found that there was a relationship between work period, back posture, body weight and the incidence of low back pain. The working period causes a continuous static load and workers who do not pay attention to ergonomic factors will cause complaints from Lumbago or LBP (Alfiani, L \& Basri S K, 2016).

One of the factors that influence the incidence of lumbago in workers is the length of sitting. The results of research conducted by Wulandari, 2010 on the relationship between length and sitting attitude towards complaints of myogenic low back pain in students at the Muhammadiyah University of Surakarta, it was found that there was a relationship between the length and attitude of sitting in lectures on complaints of myogenic lower back pain in students of the Semester DIII Physiotherapy study program. IV Faculty of Medical Sciences UMS. The length of time sitting makes the spine and tendon and muscle tissue forced to keep the upper body excessively.This will cause fatigue in the back muscle tissue, especially the lumbar muscles. This results in complaints of soreness in the lower back. After sitting for 15-20 minutes, the muscles in the back usually begin to get tired and begin to feel lower back pain. Sitting duration> 4 hours has a relationship with complaints of NPB. According to a literature review from Samara et al. Stated that sitting for 1.5 to 5 hours has a 2.35 times greater risk of developing low back pain. Workers who have a sitting position for half a day of work time or more have a 1.6 times risk of suffering from low back pain (Sari et al., 2015).

When doing activities or work, a person is required to use several body positions such as an upright sitting position, a bent sitting position and a half-sitting position (Todingan, 2015). The sitting position is a working position where the legs are not burdened with body weight and a stable position during work. According to the results of research conducted by Widjayanti Dan Pratiwi, 2013 regarding the relationship between sitting position and complaints of low back pain at STIKES Catholic St. Vincentius A Paulo Surabaya, it was found that there was a relationship between sitting position and complaints of low back pain in students at St. Vincent's Catholic STIKES A Paulo Surabaya. The factor that determines whether or not a sitting posture or sitting position is efficient at work is placing balanced pressure on different parts of the body, requires a little muscle effort to endure and feels comfortable for each worker (Tarwaka, 2018). Working while sitting must be done ergonomically so that it can provide comfort at work. If the sitting position is not ergonomic, it will cause the back muscles to become tense and can damage the surrounding soft tissue (Wijana, 2016).

Based on the results of research conducted at the Margantara Jaya Tulungagung Cigarette Factory the majority ( $85 \%$ ) of Kretek Hand Cigarette workers experienced a lumbago incident. Lumbago is a pain in the lower back, which is a musculoskeletal disorder caused by poor body activity. The risk factors that influence the incidence of lumbago include age, body mass index, sex, smoking, workload, duration or length of work, work position, repetition, years of service. The working period is the accumulation of work activities for hand-rolled kretek cigarette workers over a long period of time. If this activity is carried out continuously over a period of years, of course, it can cause disturbances in the body, especially disorders of the lower back which will cause pain. Back pain or lumbago is caused due to tension in the vertebrae, especially in the lumbar. Back pain can occur in working 
situations for Hand-Kretek Cigarette workers, but the risk is greater if the Hand-Kretek Cigarette worker sits for too long in the wrong sitting position, this will cause continuous muscle contraction and constriction of blood vessels. It is better if working while sitting should be done ergonomically so that it can provide comfort at work and minimize the incidence of lumbago in hand-rolled kretek cigarette workers at Margantara Jaya Cigarette Factory in Tulungagung.

\section{CONCLUSION}

Based on the results of research and statistical analysis, the researcher can formulate a conclusion that there is a joint influence on the factors of work tenure, sitting time and sitting position on the incidence of lumbago in hand-rolled kretek cigarette workers at Margantara Jaya Cigarette Factory in Tulungagung and the value of Exp (B) 187,663 It can be seen that the factor that most influences the incidence of lumbago in hand-rolled kretek cigarette workers at Margantara Jaya Cigarette Factory in Tulungagung is the sitting position factor. It is hoped that workers pay attention to their sitting position and take the time to stretch their muscles at work to prevent or reduce the incidence of Lumbago and for cigarette factory owners to increase their concern for workers' health and facilitate the presence of chairs that can support the lower back in order to reduce and prevent it. the occurrence of Lumbago.

\section{ACKNOWLEDGMENTS}

We express our deepest gratitude to the Director of Cigarettes Margantara Jaya for their support. We also thank all respondents who have been willing and participated in this research.

\section{CONFLICTS OF INTEREST}

The author declares that they have no conflict of interest

\section{REFERENCES}

Alfiani, L \& Basri S K. (2016). IMT Dan Masa Kerja Terhadap Keluhan Nyeri Punggung Bawah Pada Buruh Panggul. Fakultas Kesehatan Masyarakat Universitas Wiralodra. Jurnal Kesehatan Masyarakat. Vol.1. No.4

Defriyan. (2011) .Faktor-Faktor yang Berhubungan dengan Keluhan Nyeri Punggung Bawah Pada Proses Penyulaman Kain Tapis di Sanggar Family Art Bandar Lampung. Skripsi. Tidak Di terbitkan. Universitas Islam Negeri Syarif Hidayatullah : Jakarta

Fauzan MT. (2013). Hubungan Antara Faktor Pekerjaan Dengan Kejadian Low Back Pain Pada pekerja Servis Industri bengkel Mobil di Makassar Tahun 2013. Skripsi.. Fakultas Kedokteran Universitas Hasanuddin : Makassar

Lailani, M. T. (2013). Hubungan antara peningkatan indeks massa tubuh dengan kejadian nyeri punggung bawah pada pasien rawat jalan di poliklinik saraf RSUD Dokter Soedarso Pontianak. Naskah Dipublikasikan.

Muttaqin, Arif. (2008). Buku Ajar Asuhan Keperawatan Dengan Gangguan Sistem Persyarafan. Jakarta: Salemba Medika

Noor Z.H. (2012).Buku Ajar Gangguan Muskuloskeletal. Jakarta: Salemba Medika

Nurmianto, E. (2015).Ergonomi Konsep Dasar dan Aplikasinya. Surabaya: GunaWidya. Edisi I. CetakanII.

Santoso, G. (2013). Ergonomi Terapan. Jakarta: Prestasi Pustaka Publisher

Sari, Theresia, I., \&Engeline, A. (2015). Hubungan Lama Duduk Dengan Kejadian Low Back Pain Pada Operator Komputer Perusahaan Travel. Manado: Jurnal e-Clinic $(e \mathrm{Cl})$.

Syuhada Dkk. (2018). Faktor- Faktor Low Back Pain Pada Pekerja Pemetik Teh di Perkebunan Teh Ciater Kabupaten Subang.http: //perpustakan. uns.ac.id

Tarwaka. (2018). Keselamatan dan Kesehatan Kerja, Manajemen dan implementasi K3 di tempat kerja. Surakarta: Harapan Press

Todingan, M. (2015). Lapsus Low Back Pain .Jakarta : Erlangga

Umami AR, Hartanti RI, Dewi A. (2014). Hubungan Antara Karakteristik Responden dan Sikap Kerja Duduk dengan Keluhan Nyeri Punggung Bawah Pada Pekerja Batik Tulis. e-Jurnal Pustaka Kesehatan

Widjayanti et all. (2013). Faktor- Faktor yang Berhubungan Dengan Kejadian Low Back Pain Pada Pekerja Furniture.http: //perpustakan. uns.ac.id

Wijana, Nyoman. (2016). Pengelolaan Lingkungan Hidup. Yogyakarta: Plantaxia

World Health Organization. (2013). Low Back Pain. Priority Medicines for Europe and The World. 